Article

\title{
Space Efficiency in Contemporary Supertall Residential Buildings
}

\author{
Hüseyin Emre Ilgın
}

check for

updates

Citation: Ilgın, H.E. Space Efficiency in Contemporary Supertall Residential Buildings. Architecture 2021, 1, 25-37. https://doi.org/ 10.3390/architecture1010004

Academic Editor: Alessandro Zona

Received: 9 June 2021

Accepted: 31 August 2021

Published: 3 September 2021

Publisher's Note: MDPI stays neutral with regard to jurisdictional claims in published maps and institutional affiliations.

Copyright: (C) 2021 by the author. Licensee MDPI, Basel, Switzerland. This article is an open access article distributed under the terms and conditions of the Creative Commons Attribution (CC BY) license (https:/ / creativecommons.org/licenses/by/ $4.0 /)$.
School of Architecture, Faculty of Built Environment, Tampere University, FI-33014 Tampere, Finland; emre.ilgin@tuni.fi

\begin{abstract}
Space efficiency is one of the most important design considerations in any tall building, in terms of making the project viable. This parameter becomes more critical in supertall $(300 \mathrm{~m}+)$ residential towers, to make the project attractive by offering the maximum usage area for dwellers. This study analyzed the space efficiency in contemporary supertall residential buildings. Data was collected from 27 buildings, using a literature survey and a case study method, to examine space efficiency and the main architectural and structural design considerations affecting it. The results of this research highlighted that: (1) central core was the most common type of design parameter; (2) prismatic forms were the most preferred building forms; (3) the frequent use of reinforced concrete was identified, compared to steel and composite; (4) the most common structural system was an outriggered frame system; (5) the space efficiency decreased as the building height increased, in which core planning played a critical role; (6) when building form groups were compared among themselves, no significant difference was found between their effects on space efficiency, and similar results were valid for structural systems. It is believed that this study will help and direct architects in the design and implementation of supertall residential projects.
\end{abstract}

Keywords: supertall residential building; space efficiency; building form; core planning; structural system; structural material

\section{Introduction}

At the end of the 19th century, beginning with the invention of the elevator system as a form of vertical transportation with a metal rigid frame as the structural system, the construction of tall buildings emerged as an American building type, owing to the advances in structural systems, high-strength concrete, and mechanical systems. This is the main driver stimulating the race for height in tall buildings that has spread around the world [1] Furthermore, over the years, the number of supertall buildings has been increasing.

As a new 21st century phenomenon, supertall residential towers are associated with socio-technical developments [2-5]. The diffusion of these typologies, that often seem contextually unrelated to the regions or cultures in which they were erected, can be divided into three main periods [6-8]: (1) the period before the global financial crisis, when the first examples were built in Australia (before 2008), as in the case of Q1 Tower (Gold Coast, 2005); (2) the global period in which typology proliferates in Europe, Asia and the Middle East (2010-2015), as in the case of Princess Tower (Dubai, 2012); (3) the pencil-tower period in Manhattan (2015-2018), as in the case of 432 Park Avenue (New York, 2015).

Approximately 13\% of supertall buildings that were completed as of the 2000s have residential use only [9], where increasing the rentable area is one of their most crucial design inputs. At this point, the term 'space efficiency' comes to the forefront, as the residential function is expected to meet the investment cost. As an essential input for financial return, space efficiency is affected by the service core arrangement, size of the floor plan, and structural elements.

In the literature, many studies have been conducted on the technological, environmental, social, and financial aspects of the tall building phenomenon (e.g., [10-15]), whereas a 
limited number of studies have concentrated on the interrelated decisions regarding the space efficiency of tall buildings, with a limited number of sample buildings. Among them, in the study carried out by Kim and Elnimeiri [16], architectural considerations for the design of multi-use tall buildings (including the function, lease span, and floor-to-floor height) were scrutinized, alongside their interrelation with space efficiency, by analyzing 10 case studies. It was found that: (i) space efficiency should be considered together with other efficiencies (e.g., structural and energy efficiency); (ii) functional distribution determines the space efficiency; (iii) space efficiency could be improved when the optimum structural systems and building forms are developed together. Additionally, Sev and Özgen [17] conducted a similar comparative study on 10 high-rise office cases from Turkey and across the world in terms of space efficiency, where lease span, floor-to-floor height, core planning, and the structural system and materials were assessed as the main considerations. This study highlighted that: (i) the structural system, together with the core arrangement, were the most critical factors affecting space efficiency; (ii) the central core typology was the most frequently used type; (iii) a reinforced concrete tube-in-tube (without an outrigger system), and composite mega-columns (with a central core and an outrigger) were the two most common structural systems; (iv) the efficiency of the net-to-gross floor area was crucial for creating a balance between the construction cost and the entire rental rate. On the other hand, Nam and Shim [18] focused on the effect of tall buildings' corner shapes on the spatial efficiency of their inner use of the space. Some of their significant findings were as follows: the average effect on spatial efficiency is approximately $4 \%$ higher than the building with no corner cuts, and the relationship between the lease span and its spatial efficiency is directly proportional.

It is also worth noting that, in the literature, concerns about the sustainability, ecologicality, or circular economy of supertall buildings have been raised in many studies (e.g., [19-22]). For example, according to Al-Kodmany [20], these buildings have features that hinder their social, economic, and environmental sustainability. From a social perspective, because of their vertical arrangement, supertall buildings can encourage social isolation and are, therefore, often considered unsuitable for family life and child rearing in general. Furthermore, they have mostly been turning into a group of progressively self-referential, inward-focused, and vertically stratified objects, without cultural and/or social references to their surroundings [23-25]. On the other hand, from an economic standpoint, supertall towers are costly to construct because they require complex structural, mechanical, and electrical systems. They also necessitate far greater amounts of materials and energy to be built and run, and far greater amounts of embodied energy to be involved, in comparison to low-rise buildings [26]. From an environmental perspective, the construction and maintenance of supertall buildings results in large amounts of carbon dioxide emissions. Moreover, due to their great height and gigantic size, they can interfere with natural ventilation by negatively affecting wind patterns.

Furthermore, the contemporary history of supertall residential towers, often unrelated to the cities, cultures, and geographies in which they were built, can be regarded as the history of their technical progress, rather than the differences and development of their architectural, contextual, or typological features [8].

This paper aims to identify, collect, and combine the information about space efficiency in contemporary supertall residential buildings, from the standpoint of the main architectural and structural design considerations, to understand how space efficiency differs, along with what the buildings' key design features are. To achieve this goal, information was gathered from 27 case studies, including the tallest residential buildings completed in the last two decades.

Regarding the scope of the study, four main points were used to scrutinize the significant parameters for design and their relationship with space efficiency in supertall residential construction: general information (building name, country and city, height, number of stories, and completion date), main design considerations affecting space efficiency (core planning, building form, structural system, and structural material), space 
efficiency, and interrelation of space efficiency and main design considerations. Consequently, this study, which reveals the current state of supertall residential applications, provides insights into making more viable design decisions for future living at height.

\section{Research Methods}

This study was conducted using a comprehensive literature survey, including the Council of Tall Building and Urban Habitat database [9], peer-reviewed papers, MSc and $\mathrm{PhD}$ dissertations, and conference proceedings, as well as architectural and structural design magazines. Besides this, the case study method was used to identify, collect, and combine the information about contemporary supertall residential buildings, to examine critical parameters for the design and their relationships with space efficiency. These selected cases were 27 contemporary supertall residential towers from different countries (4 from Asia (Korea and India), 13 from the Middle East, 6 from North America, 2 from Russia, and 2 from Australia) [9]. Furthermore, in this study, exceptionally detailed information about supertall residential towers was analyzed (see Tables 1 and 2), where those without adequate information about their load-bearing systems and floor plans were excluded from the building list. Taking building form into account, a vigorous effort was made in finding and selecting floor plans, which were from lower levels, to create comparable and consistent data for space efficiency in 27 cases. The case study method is a commonly used approach to assessments of the built environment, where projects are identified and recorded for qualitative and quantitative data analysis by utilizing an in-depth literature review (e.g., $[27,28])$.

Table 1. Contemporary supertall residential buildings.

\begin{tabular}{|c|c|c|c|c|c|c|}
\hline$\#$ & Building Name & Country & City & Height (m) & \# of Stories & Completion \\
\hline 1 & Chicago Spire & United States & Chicago & 609 & 150 & $\mathrm{NC}$ \\
\hline 2 & Pentominium Tower & UAE & Dubai & 515 & 122 & $\mathrm{OH}$ \\
\hline 3 & Central Park Tower & United States & New York & 472 & 98 & 2020 \\
\hline 4 & Marina 106 & UAE & Dubai & 445 & 104 & $\mathrm{OH}$ \\
\hline 5 & World One & Mumbai & India & 442 & 117 & NC \\
\hline 6 & 111 West 57th Street & United States & New York & 435 & 84 & $\mathrm{UC}$ \\
\hline 7 & 432 Park Avenue & United States & New York & 425 & 85 & 2015 \\
\hline 8 & Princess Tower & UAE & Dubai & 413 & 101 & 2012 \\
\hline 9 & 23 Marina & UAE & Dubai & 392 & 88 & 2012 \\
\hline 10 & Burj Mohammed Bin Rashid & UAE & Abu Dhabi & 381 & 88 & 2014 \\
\hline 11 & Elite Residence & UAE & Dubai & 380 & 87 & 2012 \\
\hline 12 & II Primo Tower 1 & UAE & Dubai & 356 & 79 & UC \\
\hline 13 & The Torch & UAE & Dubai & 352 & 86 & 2011 \\
\hline 14 & NEVA TOWERS 2 & Russia & Moscow & 345 & 79 & 2020 \\
\hline 15 & LCT The Sharp Residential Tower A & Korea & Busan & 339 & 85 & 2019 \\
\hline 16 & DAMAC Heights & UAE & Dubai & 335 & 88 & 2018 \\
\hline 17 & LCT The Sharp Residential Tower B & Korea & Busan & 333 & 85 & 2019 \\
\hline 18 & Q1 Tower & Australia & Gold Coast & 322 & 78 & 2005 \\
\hline 19 & Palace Royale & Mumbai & India & 320 & 88 & $\mathrm{OH}$ \\
\hline 20 & 53 West 53 & United States & New York & 320 & 77 & 2019 \\
\hline 21 & Australia 108 & Australia & Melbourne & 316 & 100 & 2020 \\
\hline
\end{tabular}


Table 1. Cont.

\begin{tabular}{|c|c|c|c|c|c|c|}
\hline$\#$ & Building Name & Country & City & Height (m) & \# of Stories & Completion \\
\hline 22 & Ocean Heights & UAE & Dubai & 310 & 83 & 2010 \\
\hline 23 & The One & Canada & Toronto & 308 & 85 & $\mathrm{UC}$ \\
\hline 24 & Amna Tower & UAE & Dubai & 307 & 75 & 2020 \\
\hline 25 & Noora Tower & UAE & Dubai & 307 & 75 & 2019 \\
\hline 26 & Cayan Tower & UAE & Dubai & 306 & 73 & 2013 \\
\hline 27 & Capital City Moscow Tower & Russia & Moscow & 301 & 76 & 2010 \\
\hline
\end{tabular}

Note on abbreviations: 'UAE' indicates the United Arab Emirates; 'NC' indicates never completed; ' $\mathrm{OH}^{\prime}$ indicates on hold; 'UC' indicates under construction.

Table 2. Supertall residential buildings by core type, building form, and structural system and material.

\begin{tabular}{|c|c|c|c|c|c|}
\hline$\#$ & Building Name & Core Type & Building Form & Structural System & Structural Material \\
\hline 1 & Chicago Spire & Central & Twisted & Outriggered frame & $\mathrm{RC}$ \\
\hline 2 & Pentominium Tower & Central & Free & Outriggered frame & $\mathrm{RC}$ \\
\hline 3 & Central Park Tower & Central & Setback & Outriggered frame & $\mathrm{RC}$ \\
\hline 4 & Marina 106 & Central & Prismatic & Framed-tube & $\mathrm{RC}$ \\
\hline 5 & World One & Central & Setback & Buttressed core & $\mathrm{RC}$ \\
\hline 6 & 111 West 57 th Street & Peripheral & Setback & Outriggered frame & $\mathrm{RC}$ \\
\hline 7 & 432 Park Avenue & Central & Prismatic & Framed-tube & $\mathrm{RC}$ \\
\hline 8 & Princess Tower & Central & Prismatic & Framed-tube & $\mathrm{RC}$ \\
\hline 9 & 23 Marina & Central & Prismatic & Outriggered frame & $\mathrm{RC}$ \\
\hline 10 & Burj Mohammed Bin Rashid & Central & Free & Outriggered frame & $\mathrm{RC}$ \\
\hline 11 & Elite Residence & Central & Prismatic & Framed-tube & $\mathrm{RC}$ \\
\hline 12 & Il Primo Tower 1 & Central & Prismatic & Outriggered frame & $\mathrm{RC}$ \\
\hline 13 & The Torch & Central & Prismatic & Outriggered frame & $\mathrm{RC}$ \\
\hline 14 & NEVA TOWERS 2 & Central & Prismatic & Outriggered frame & $\mathrm{RC}$ \\
\hline 15 & LCT The Sharp Residential Tower A & Central & Prismatic & Outriggered frame & $\mathrm{RC}$ \\
\hline 16 & DAMAC Heights & Central & Tapered & Outriggered frame & $\mathrm{RC}$ \\
\hline 17 & LCT The Sharp Residential Tower B & Central & Prismatic & Outriggered frame & $\mathrm{RC}$ \\
\hline 18 & Q1 Tower & Central & Prismatic & Outriggered frame & $\mathrm{RC}$ \\
\hline 19 & Palace Royale & Central & Prismatic & Outriggered frame & $\mathrm{RC}$ \\
\hline 20 & 53 West 53 & Peripheral & Tapered & Diagrid-framed-tube & $\mathrm{RC}$ \\
\hline 21 & Australia 108 & Central & Free & Outriggered frame & $\mathrm{RC}$ \\
\hline 22 & Ocean Heights & Central & Tapered & Outriggered frame & $\mathrm{RC}$ \\
\hline 23 & The One & Central & Prismatic & Outriggered frame & Composite \\
\hline 24 & Amna Tower & Central & Prismatic & Outriggered frame & $\mathrm{RC}$ \\
\hline 25 & Noora Tower & Central & Prismatic & Outriggered frame & $\mathrm{RC}$ \\
\hline 26 & Cayan Tower & Central & Twisted & Framed-tube & $\mathrm{RC}$ \\
\hline 27 & Capital City Moscow Tower & Central & Free & Outriggered frame & $\mathrm{RC}$ \\
\hline
\end{tabular}

Note on abbreviation: ' $R C^{\prime}$ indicates reinforced concrete.

Even though there is no absolute definition of what constitutes a 'tall building' (e.g., [1,21]), according to the Council on Tall Buildings and Urban Habitat (CTBUH) [9], 14 or more stories—or more than $50 \mathrm{~m}$ in height—could, characteristically, be used as a threshold for a 'tall building'. A tall building of $300 \mathrm{~m}$ or higher could be classified as 'supertall', and a tall building of $600 \mathrm{~m}$ or higher can be considered as 'megatall'. A 'supertall building' is defined as a building of $300 \mathrm{~m}$ or higher in this study. 


\section{Findings}

\subsection{Main Design Considerations Affecting Space Efficiency}

This section examines the main architectural and structural design parameters that have an effect on space efficiency in the 27 supertall residential cases. These parameters are: (i) core planning; (ii) building form; (iii) structural system; and (iv) structural material. They are considered because these parameters are among the significant architectural and structural considerations in the design of supertall buildings (e.g., [17,29-32]).

\subsubsection{Core Planning}

Core planning plays the most significant role in increasing the overall space efficiency of a building, as it is a critical architectural design parameter. The core classification suggested by Ilgin et al. [31], below, was employed in this study, owing to its more comprehensive nature compared to the existing literature (e.g., [33-35]).

- Central core (central and central split);

- Atrium core (atrium and atrium split);

- External core (attached, detached, partial split, and full split);

- Peripheral core (partial peripheral, full peripheral, partial split, and full split).

A central core design was the most common typology in the 27 cases, by a wide margin (93\%), while a peripheral core design occurred in two cases, as seen in Table 2. This result is similar to the findings by Ilgin et al. [31]. Among the 93 supertall towers in their study, 95\% were identified to have a central core typology. Similarly, in the study carried out by Oldfield and Doherty [35], 85\% of 500 tall buildings were observed to have a central core design. The advantages of a central core arrangement, such as its considerable structural contribution, its superiority in fire safety concern, and its ability to provide more openings for light and views on the exterior façade, may have enabled its prevalence [31,35]. On the other hand, low space efficiency resulting from longer circulation paths, together with challenging fire escape distances, could be considered as a weaknesses of the peripheral core configuration. Additionally, the lack of the external core typology in the case studies could be explained by its disadvantages that are similar to those of peripheral core arrangements [30].

\subsubsection{Building Form}

Building form is also an important parameter affecting the space efficiency in supertall residential buildings among the architectural design factors. Considering the accounts from the previous literature [36-38], the following classification by Ilgin et al. [31] was used to categorize the form of the 27 cases in this study:

- Prismatic forms;

- $\quad$ Setback forms;

- Tapered forms;

- Twisted forms;

- Leaning/tilted forms;

- $\quad$ Free forms.

Based on the classification above, prismatic form was the most frequently used form in the 27 cases, with a proportion of $56 \%$ (Table 2). The reason behind this dominance could be its ease of workmanship, compared to the complex and free forms, and that it allows for the effective use of interior space (particularly for rectangular plans). On the other hand, the high gravity-induced lateral displacement, depending on the angle of the tilt, in the leaning form [39], may have contributed to this typology's absence in the general sample of supertall residential buildings.

\subsubsection{Structural System}

The selection of structural systems is a significant factor that directly affects the space efficiency of supertall residential towers because of the size and arrangement of 
the structural members. In the literature, there are numerous structural systems and classifications for supertall buildings (e.g., [1,30,40-43]. In this study, the structural system classification presented by Ilgin et al. [31] and Ilgin [32] (as shown below) was preferred, owing to its more complete nature.

- Shear-frame system;

Shear-trussed frame;

Shear-walled frame;

- Mega core system;

- Mega column system;

- $\quad$ Outriggered frame system;

- Tube system;

Framed-tube system (with the subset of diagrid-framed-tube system);

Trussed-tube system;

Bundled-tube system;

- Buttressed core system.

As shown in Table 2, an outriggered frame system was used most often (74\%) in the 27 residential cases. This was similar to the results in the study carried out by Ilgin et al. [31], where this system was predominantly (65\%) used. The common use of an outriggered frame system might be explained by its flexible nature regarding the perimeter column arrangement and, thus, providing relatively more freedom in the building's exterior composition, as well as great height potential, as in the cases of Chicago Spire and Pentominium Tower. While a tube system (framed-tube) was preferred in six cases, there was only one case with a buttressed core system.

\subsubsection{Structural Material}

Structural material selection is another critical factor that directly affects the space efficiency of supertall residential buildings because of its effect on the dimensions of the structural members. Structural materials can be categorized as follows: (i) steel; (ii) reinforced concrete (RC); (iii) composite. Considering columns, beams, shear trusses and walls, and outriggers as the main structural components, this study used 'composite' to refer to: a construction in which some of the structural members are made of RC and other structural members are made of steel; those in which some structural members are made of both structural steel and RC together; a combination of both of these.

As a structural material, reinforced concrete was predominantly $(>96 \%)$ used for supertall residential construction (Table 2), unlike the findings in the study carried out by Ilgin et al. [31], where composite was the most preferred (66\%) structural material. The prevalence of reinforced concrete might be explained by its cost-competitiveness in many countries, its comparative ease of use in construction and manufacturing, its fire-resistant nature, and its stronger performance in mitigating wind-induced building sway, compared to steel.

\subsection{Space Efficiency}

The term 'space efficiency' can be described as the ratio of Net Floor Area Over Gross Floor Area. Taking the codes and regulations into consideration, to secure the maximum return for the investor, building floors should provide the sufficient space for functional operations; that is, high space efficiency [16]. As underlined in the previous sections, space efficiency is determined by core planning, building form, the structural system, and the structural material. These parameters vary according to the architectural and structural needs, which are the main decision-making criteria in the design of supertall residential towers, as they are in many buildings. Among these, for example, core planning affects the arrangement and distribution of the vertical mobility of shafts [44], while building form has an effect on slab size and shape [17]. On the other hand, while the structural system affects the dimensions and placement of the building's elements [31], the building material 
has an effect on the dimensions of the building's elements [30]. Therefore, these four factors all have an impact on space efficiency. Furthermore, space efficiency can be increased by the lease span, which can be defined as the distance between a fixed interior element (e.g., core wall) and an exterior envelope (e.g., window).

Based on the studies carried out by Yeang $[33,45], 75 \%$ could be taken as a threshold value of space efficiency in the design of high-rise buildings. However, as the building gets taller, securing high space efficiency turns into a more difficult task to achieve, because of the increase in size of the core area and structural elements that is necessary to resist particularly lateral loads, and to meet the requirements of vertical circulation [46,47]. In a comparative study focusing on 10 high-rise office cases from Turkey and across the world, Sev and Özgen [17] found that the space efficiency and core over gross floor area ratio changed from $60 \%$ to $77 \%$, and from $22 \%$ to $30 \%$, with average values of $69 \%$ and $26 \%$, respectively. In the current research, the average space efficiency and core over gross floor area ratio of the 27 cases were $76 \%$ and $19 \%$, respectively; ranging from $56 \%$ and $11 \%$ at the lowest, to $84 \%$ and $36 \%$ at the highest, respectively (see Figure 1).

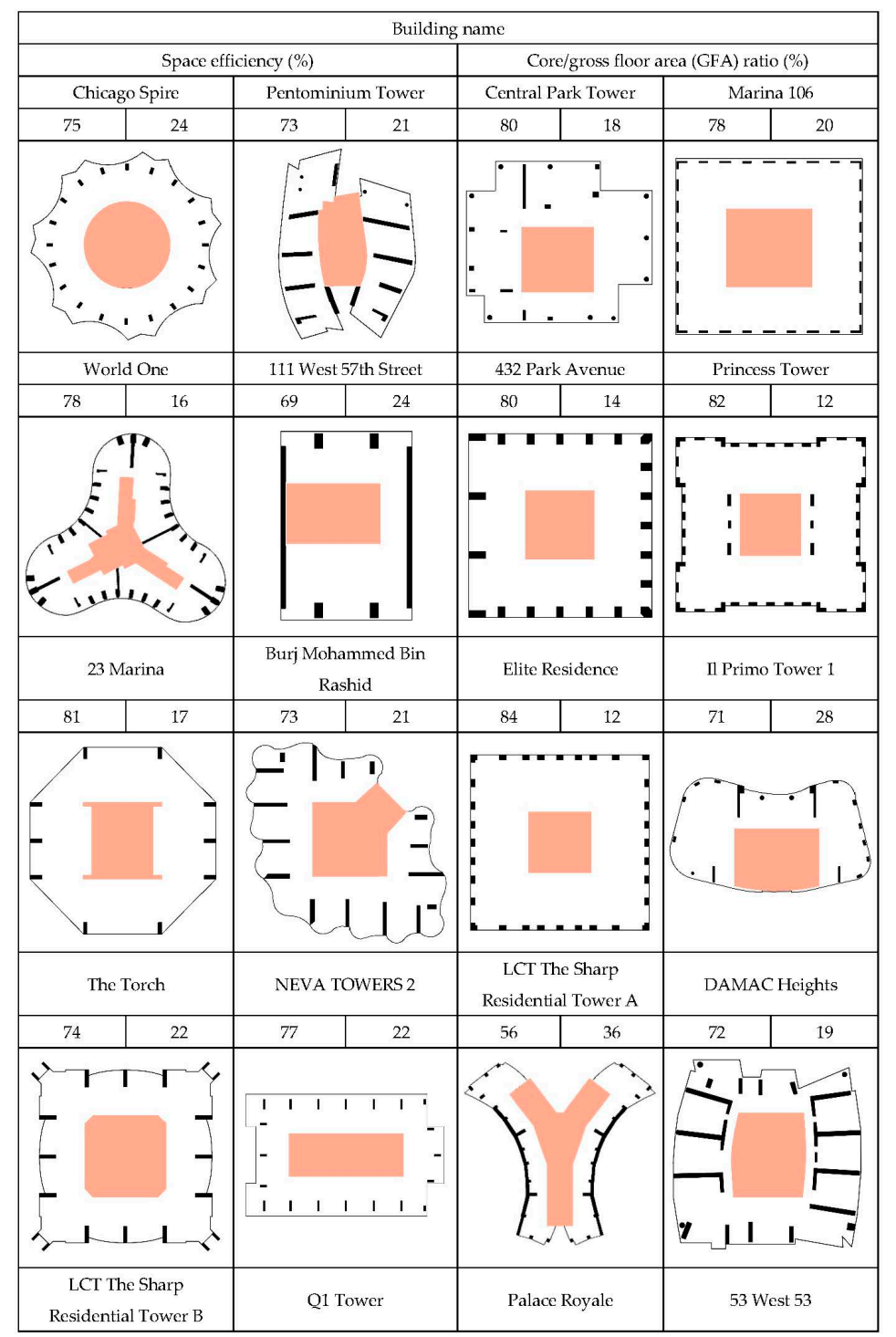

Figure 1. Cont. 


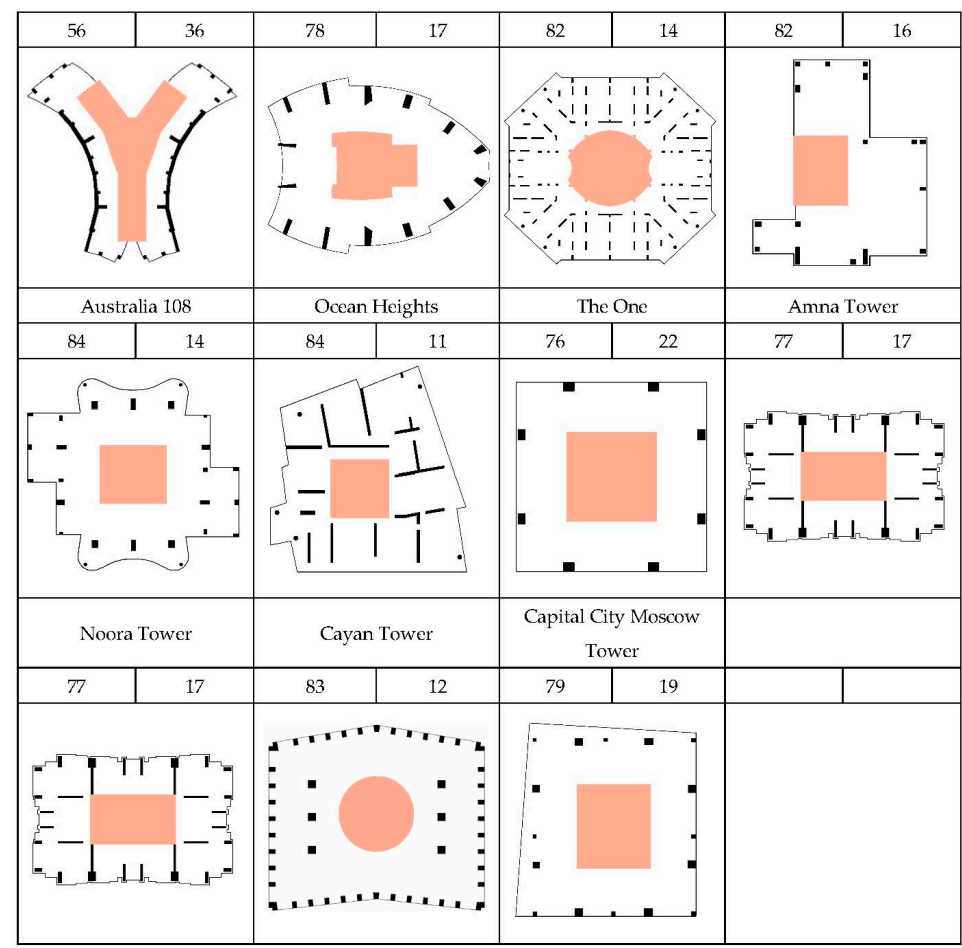

Figure 1. Floor plans of supertall residential with space efficiency (\%) and core/gross floor area ratio $(\%)$.

Among the 27 cases, Elite Residence, Australia 108, and Ocean Heights have the highest space efficiencies (84\%), and low ratios of core over gross floor area (11-14\%). The main reason behind these remarkable ratios might be explained by the effective and compact layout of the circulation elements that may have helped to keep the core area small.

\subsection{Interrelations of Space Efficiency and Main Design Considerations}

The interrelations of space efficiency and the main design considerations affecting it, such as building height, building form, and structural system was examined in this section.

Since reinforced concrete was the most frequently used building material $(>96 \%)$ and the central core type was the most preferred typology $(93 \%)$ in the case studies, no analysis was carried out regarding the interrelation between space efficiency and structural material, or space efficiency and core planning.

The interrelations detailed below were explored from the perspective of supertall residential buildings, to provide an introductory design guide for architects and developers.

\subsubsection{Interrelation of Space Efficiency and Building Height}

Figure 2a,b demonstrates how space efficiency changes based on the building height, where black dots represent the supertall residential buildings in this study. Buildings at $333 \mathrm{~m}$ and $339 \mathrm{~m}$ heights, with a space efficiency ratio of $56 \%$, and a core over gross floor ratio of $36 \%$, can be considered as outliers, and Figure $2 b$ shows how these outliers quantitatively affect the regression line. As shown by the red trendline in Figure $2 \mathrm{a}$, space efficiency tends to decrease as the building gets higher, and, as seen in Figure $2 b$, this reduction becomes much more pronounced when the two outliers are removed. Therefore, it can be stated that, as the height of the building increases in supertall residential buildings, the space efficiency decreases. This can be explained by the fact that the higher the building, the more difficult it is to achieve high space efficiency, due to the increase in the size of both the core areas and structural components. 


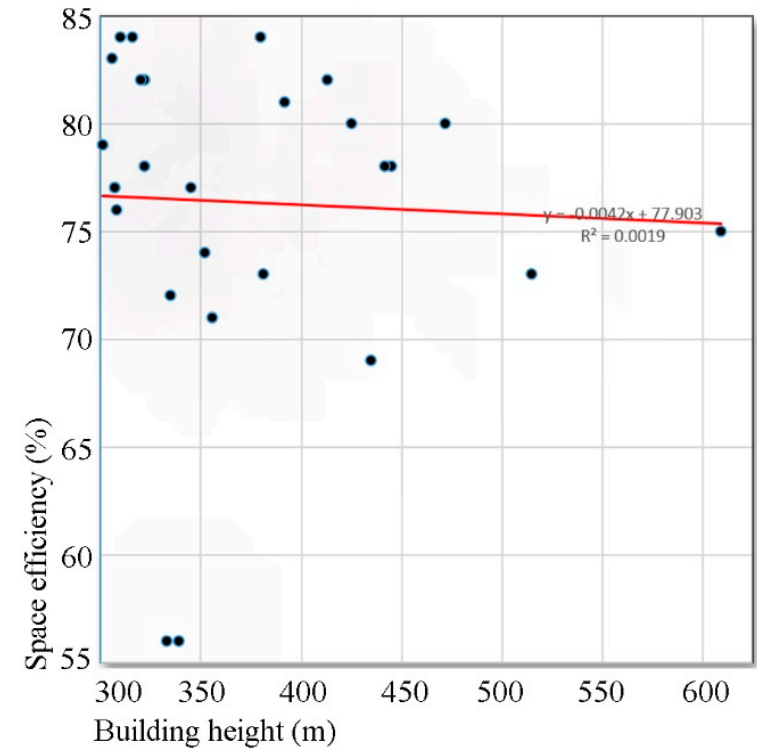

(a)

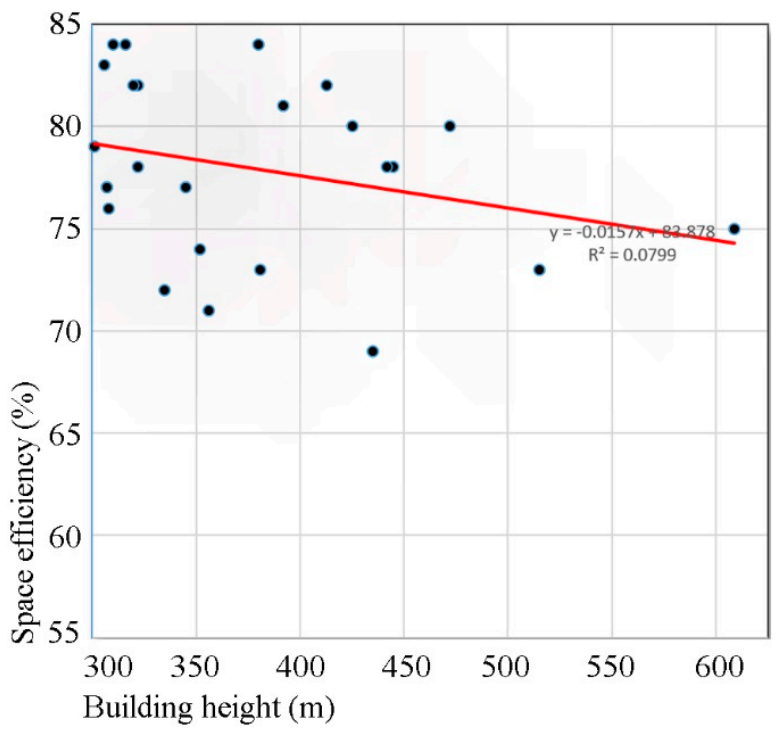

(b)

Figure 2. Interrelation of space efficiency and building height: (a) with outliers, (b) without outliers.

Furthermore, Figure $3 \mathrm{a}$, b shows that the taller the residential building, the more core space is needed. When the aforementioned outliers are removed, this relationship becomes more pronounced, as seen in Figure $3 b$. This can be considered as another manifestation of the above fact.

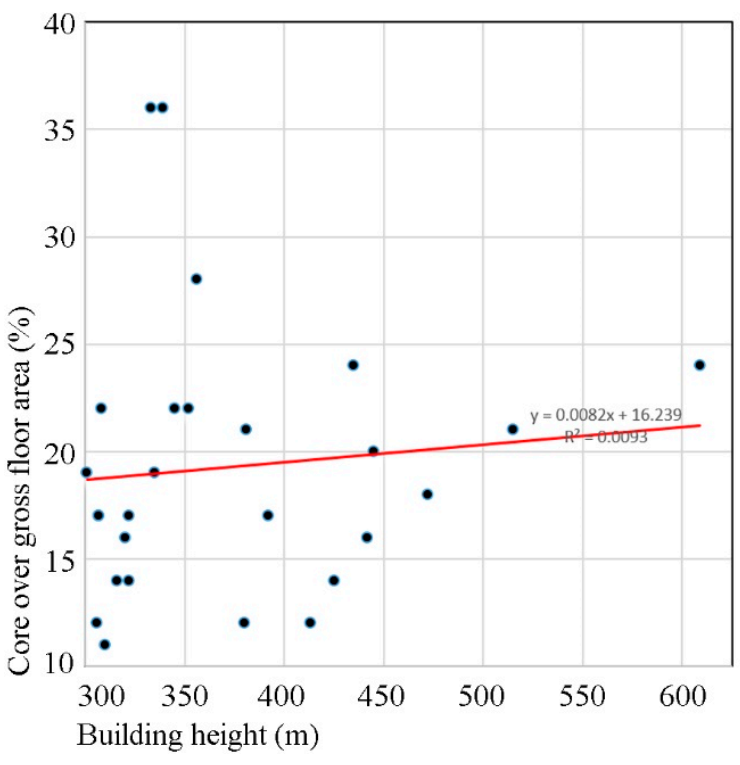

(a)

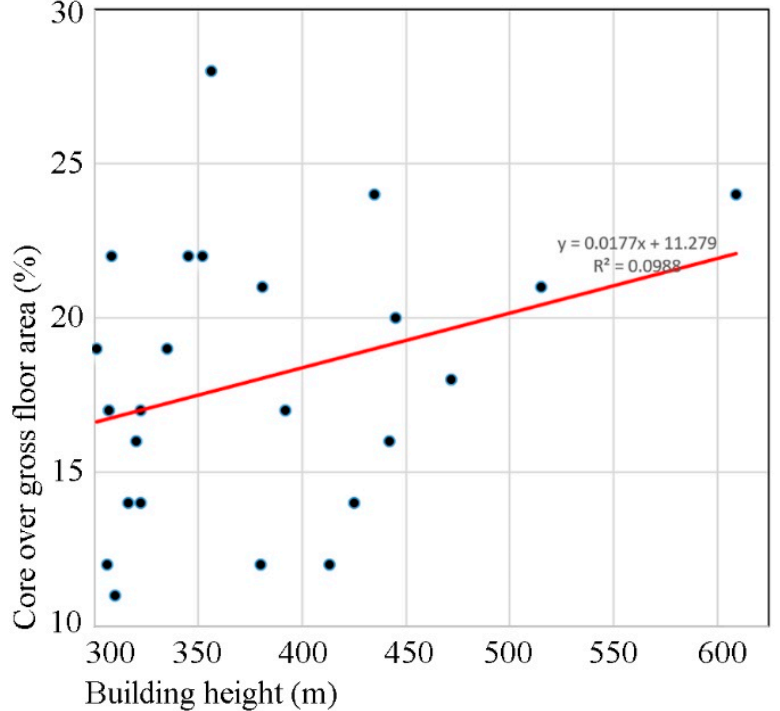

(b)

Figure 3. Interrelation of the ratio of core over gross floor area and building height: (a) with outliers, (b) without outliers.

\subsubsection{Interrelation of Space Efficiency and Building Form}

In Figure 4, the bars show the total number of supertall residential buildings with respect to the building form (right axis of the chart), while the dots correspond to the space efficiency of these buildings for this type of building form (the left axis of the chart). 


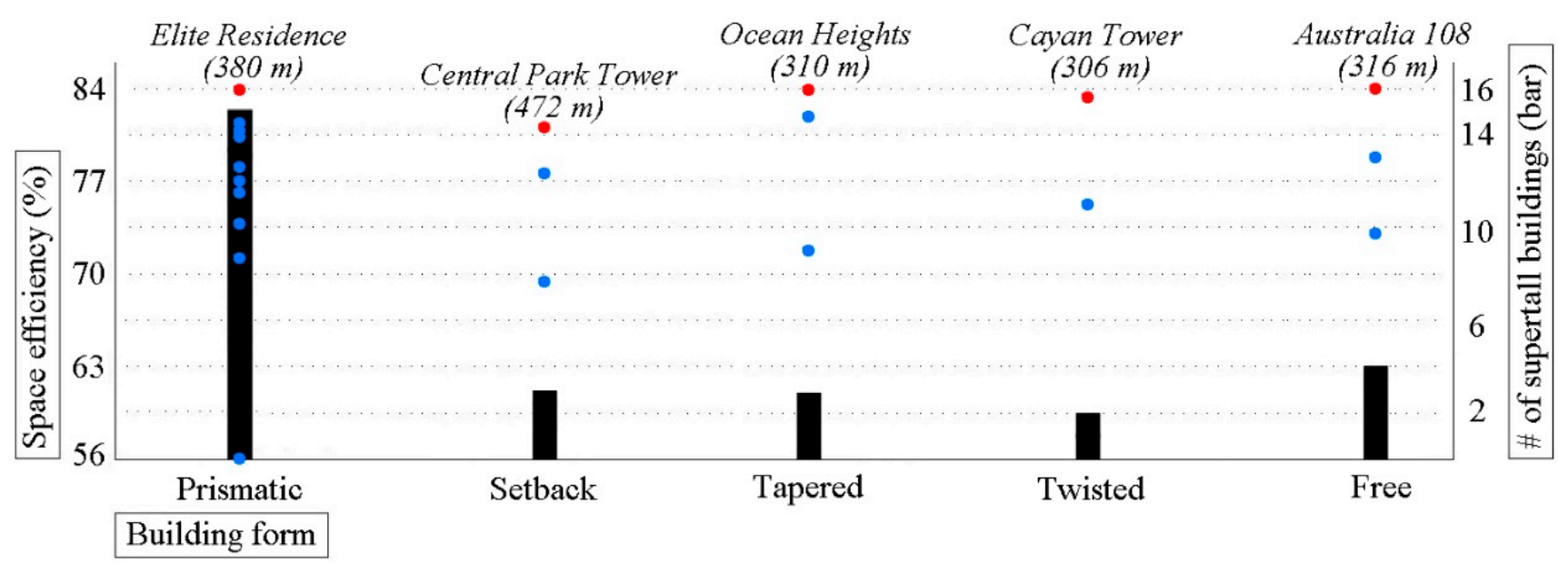

Figure 4. Interrelation of space efficiency and building form.

As highlighted in Figure 4, the space efficiency of buildings with a prismatic form ranges between $56 \%$ (only in two cases) and $84 \%$, with an average of $77 \%$; while the average space efficiency of four supertall residential towers with a free form is $73 \%$. Since the number of setback (three, with an average space efficiency of $76 \%$ ), tapered (three, with an average space efficiency of $79 \%$ ), and twisted (two, with an average space efficiency of $79 \%$ ) forms is very small, it is difficult to establish an interrelation between space efficiency and these building forms in a scientific manner.

As a result, considering the average values above, there are no significant differences among the building groups regarding the different building forms analyzed in this study.

\subsubsection{Interrelation of Space Efficiency and Structural System}

In Figure 5, the bars show the total number of supertall residential buildings with respect to the structural system (right axis of the chart), while the dots correspond to the space efficiency of these buildings for this type of structural system (the left axis of the chart).

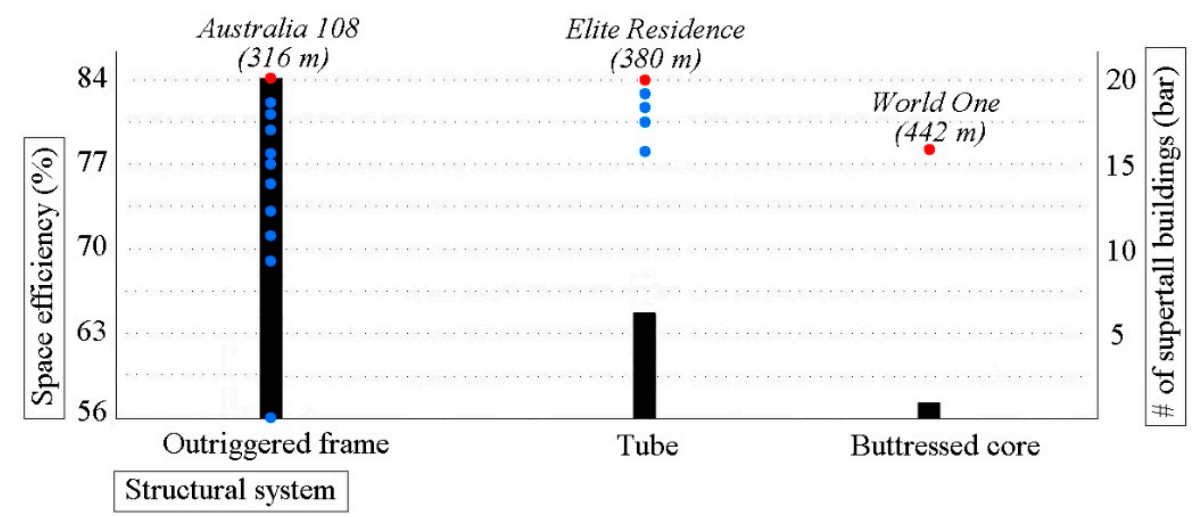

Figure 5. Interrelation of space efficiency and structural system.

As seen in Figure 5, the space efficiency of buildings with an outriggered frame system ranges between $56 \%$ (only in two cases) and $84 \%$, with an average of $75 \%$. A buttressed core system is the least preferred type (only appearing in one case) for the construction of supertall residential buildings, based on the study's sample. As there is only one case with a buttressed core system, deriving a correlation between space efficiency and the structural system of this building is likely to be inaccurate. The space efficiency of buildings with tube systems has an average of $81 \%$.

In supertall residential towers, there is no significant difference in the effect of the use of tube and outriggered frame systems on space efficiency, and if the outliers (mentioned in 
Section 3.3.1) are removed, the average space efficiency in the buildings with an outriggered frame system increases to $77 \%$.

\section{Discussion and Conclusions}

This study was based on the main architectural and structural parameters that have an effect on space efficiency (including core planning, building form, the structural system, and the structural material) in the design of supertall residential buildings, to help and direct architects in the generation of economically sound and feasible supertall residential projects.

The central core design was the most used type, as was also reported in the research by Sev and Özgen [17], Ilgin et al. [31], Ilgin [32], and Oldfield and Doherty [35]. Its ease of integration into the main structural system to resist vertical and lateral loads more efficiently, together with its potential for allowing more daylight and views through the building exterior may have contributed to the dominance of this arrangement. On the other hand, unlike Ilgin's study [32] on supertall office buildings (in which the frequent use of tapered and free forms was identified), prismatic forms were the most preferred building forms in supertall residential construction. This may indicate the architects' tendency towards reasonable interior planning, to create a more efficient and leasable interior layout, compared to sophisticated floor plans. Furthermore, as a structural advantage, these comparatively uncomplicated and symmetrical floor layouts provide similar lateral stiffness in each direction.

As was found in the studies carried out by Ilgin et al. [31] and Ilgin [32], the most commonly used structural system was the outriggered frame system. However, unlike these studies [31,32], the statistics regarding the structural materials showed that reinforced concrete was the most preferred material in the design of residential towers. Its reasonable price in the construction markets of many regions, its ease of use in both production and construction, as well as its natural fire resistance features may have helped to make reinforced concrete the dominant choice in residential use at height.

Similar to other studies in the literature (e.g., [32]), the findings of this study highlighted that space efficiency decreased as the building height increased. Additionally, the core design played a critical role in the space efficiency of supertall residential towers, because its planning and dimensions directly affected the net floor area, as was also stated in the studies carried out by Sev and Özgen [17], and Ilgın [32]. On the other hand, when the building form groups were compared among themselves, no significant differences were observed in their effects on space efficiency. Similar results were also valid for the structural systems group; namely, the outriggered frame and tube systems were the most preferred types in the buildings that were analyzed in this study. The selection of the structural system suitable for the relevant building may have resulted in similar ratios among the structural system groups.

It is also worth mentioning that supertall residential towers have faced the accusation that they are an unsustainable building type in many ways, including social, economic, and environmental considerations. Strategies to overcome these critical issues should be developed from the very beginning of the planning phase. In this sense, the design of supertall residential buildings, like many other complex structures, is a complicated task that requires interdisciplinary collaboration and advanced teamwork, and architects, in particular, must be aware of this fact.

In this study, 27 supertall residential towers (300 $\mathrm{m}$ or taller) were examined regarding their main architectural and structural design parameters, to provide a step towards analyzing space efficiency as one of the key design parameters to make a project viable. In addition to the general facts, information about core planning, building form, the structural system, the structural material, and the interrelations between space efficiency and the main design considerations of contemporary supertall residential towers were analyzed.

The empirical data provided in this study was limited to completed supertall residential buildings (300 $\mathrm{m}$ or taller). However, given the increasing demand for such buildings today, it seems that many more supertall residential towers will be built in the near future. 
In addition, tall buildings below $300 \mathrm{~m}$ can be included in the sample group to increase the number of buildings examined in future studies.

Funding: This research received no external funding.

Institutional Review Board Statement: Not applicable.

Informed Consent Statement: Not applicable.

Data Availability Statement: Not applicable.

Conflicts of Interest: The author declares no conflict of interest.

\section{References}

1. Gunel, M.H.; Ilgın, H.E. Tall Buildings: Structural Systems and Aerodynamic Form; Routledge: London, UK; New York, NY, USA, 2014.

2. Jacobs, J.M.; Cairns, S.; Strebel, I.; Chau, K.-W.; Wong, S.; Yau, Y.; Yeung, A. 'A Tall Storey ... but, a Fact Just the Same': The Red Road High-rise as a Black Box. Urban Stud. 2007, 44, 609-629. [CrossRef]

3. Al-Kodmany, K. The Logic of Vertical Density: The Buildings in the 21st Century City. Int. J. High-Rise Build. $2012,1,2$.

4. Dorignon, L. High-Rise Living in the Middle-Class Suburb: A Geography of Tactics and Strategies. Ph.D. Thesis, The School of Geography, Faculty of Science, The University of Melbourne, Melbourne, Australia, 2019.

5. Guruvappan, M.; Byczynski, N.A. State-of-the-Art Engineering for Supertall Residential Buildings. In Proceedings of the 2019 Chicago 10th World Congress Proceedings-50 Forward I 50 Back, Chicago, IL, USA, 28 October-2 November $2019 ; 2019$.

6. Willis, C. The Logic of Luxury: New York's New Super-Slender Towers. In Proceedings of the CTBUH 2014 Shanghai Conference Proceedings, Shanghai, China, 16-19 September 2014; 2014.

7. Wainwright, O. Super-Tall, Super-Skinny, Super-Expensive: The 'Pencil Towers' of New York's Super-Rich; The Guardian: London, UK, 2019.

8. Radović, V. Density through the Prism of Supertall Residential Skyscrapers: Urbo-Architectural Type in Global Megacities. Sustainability 2020, 12, 1314. [CrossRef]

9. CTBUH. Council on Tall Buildings and Urban Habitat; Illinois Institute of Technology, S.R. Crown Hall: 3360 South State Street, Chicago, IL, USA, 2021; Available online: www.ctbuh.org (accessed on 15 August 2021).

10. Gunel, M.H.; Ilgin, H.E. A proposal for the classification of structural systems of tall buildings. Build. Environ. 2007, 42, 2667-2675. [CrossRef]

11. Al-Kodmany, K.; Ali, M.M. The Future of the City: Tall Buildings and Urban Design; WIT Press: Southampton, UK, 2013.

12. Moon, K.S. Developments of Structural Systems Toward Mile-High Towers. Int. J. High-Rise Build. 2018, 7, 197-214.

13. Al-Kodmany, K. Tall Buildings and the City: Improving the Understanding of Placemaking, Imageability, and Tourism; The Urban Book Series; Springer: Berlin/Heidelberg, Germany, 2020.

14. Lu, X.; Guan, H. Earthquake Disaster Simulation of Civil Infrastructures: From Tall Buildings to Urban Areas, 2nd ed.; Springer: Berlin/Heidelberg, Germany, 2021.

15. Fu, F. Fire Safety Design for Tall Buildings; CRC Press, Taylor \& Francis Group: Boca Raton, FL, USA, 2021.

16. Kim, H.; Elnimeiri, M. Space efficiency in multi-use tall building. In Tall Buildings in Historical Cities-Culture and Technology for Sustainable Cities; CTBUH: Chicago, IL, USA, 2004; pp. 748-755.

17. Sev, A.; Özgen, A. Space Efficiency In High-Rise Office Buildings. METU J. Fac. Arch. 2009, 26, 69-89. [CrossRef]

18. Nam, H.-J.; Shim, J.-H. An Analysis of the Change in Space Efficiency based on Various Tall Building Corner Shapes and Lease Spans. J. Arch. Inst. Korea Plan. Des. 2016, 32, 13-20. [CrossRef]

19. Yeang, K. Ecoskyscrapers and Ecomimesis: New tall building typologies. In Proceedings of the CTBUH 2008 8th World Congress, Dubai, United Arab Emirates, 3-5 March 2008; 2008.

20. Al-Kodmany, K. Chapter 3 Unsustainable tall building developments. In The Vertical City: A Sustainable Development Model; WIT Press: Southampton, UK, 2018.

21. Al-Kodmany, K. The Sustainability of Tall Building Developments: A Conceptual Framework. Buildings 2018, 8, 7. [CrossRef]

22. Borrallo-Jiménez, M.; LopezdeAsiain, M.; Herrera-Limones, R.; Arcos, M.L. Towards a Circular Economy for the City of Seville: The Method for Developing a Guide for a More Sustainable Architecture and Urbanism (GAUS). Sustainability 2020, $12,7421$. [CrossRef]

23. Scheeren, O. Space Formations. In Proceedings of the CTBUH 2014 Shanghai Conference Proceedings, Shanghai, China, 16-19 September 2014; pp. 67-74.

24. Henn, M.; Fleischmann, M. Novel High-rise Typologies-Towards Vertical Urbanism. In Proceedings of the CTBUH 2015 New York Conference, New York, NY, USA, 26-30 October 2015.

25. Safarik, D. The Other Side of the Tall Buildings: The Urban Habitat. CTBUH J. 2016, 1, 20-25.

26. Ali, M.M.; Al-Kodmany, K. Tall Buildings and Urban Habitat of the 21st Century: A Global Perspective. Buildings 2012 , 2, $384-423$. [CrossRef] 
27. Teegavarapu, S.; Summers, D.J. Case Study Method for Design Research. In Proceedings of the IDETC/DTM 2008 ASME 2008 International Design Engineering Technical Conferences \& Computers and Information in Engineering Conference, New York, NY, USA, 3-6 August 2008.

28. Kuzmanovska, I.; Gasparri, E.; Monne, D.T.; Aitchison, M. Tall Timber Buildings: Emerging Trends and Typologies. In Proceedings of the 2018 World Conference on Timber Engineering (WCTE 2018), Seoul, Korea, 20-23 August 2018.

29. Ali, M.M.; Armstrong, P.J. Architecture of Tall Buildings; Council on Tall Buildings and Urban Habitat Committee 30; McGraw-Hill, Inc.: New York, NY, USA, 1995.

30. Ilgin, H.E. Potentials and Limitations of Supertall Building Structural Systems: Guiding for Architects. Ph.D. Thesis, Department of Architecture, Middle East Technical University, Ankara, Turkey, 2018.

31. Ilgın, H.E.; Ay, B.Ö.; Gunel, M.H. A study on main architectural and structural design considerations of contemporary supertall buildings. Arch. Sci. Rev. 2021, 64, 212-224. [CrossRef]

32. Ilgin, H.E. Space Efficiency in Supertall Office Buildings. J. Archit. Eng. 2021, $27,3$.

33. Yeang, K. Service Cores: Detail in Building; Wiley-Academy: London, UK, 2000.

34. Trabucco, D. Historical Evolution of the Service Core. CTBUH J. 2010, 1, 42-47.

35. Oldfield, P.; Doherty, B. Offset Cores: Trends, Drivers and Frequency in Tall Buildings. CTBUH J. 2019, II, 40-45.

36. Vollers, K. Morphological Scheme of Second-Generation Non-Orthogonal High-Rises. In Proceedings of the 8th World Congress of the Council on Tall Buildings and Urban Habitat: Tall \& Green: Typology for a Sustainable Urban Future, Post Congress Review, Dubai, United Arab Emirates, 3-5 March 2008; pp. 504-512.

37. Al-Kodmany, K.; Ali, M.M. An Overview of Structural and Aesthetic Developments in Tall Buildings Using Exterior Bracing and Diagrid Systems. Int. J. High-Rise Build. 2016, 5, 271-291. [CrossRef]

38. Szolomicki, J.; Golasz-Szolomicka, H. Technological Advances and Trends in Modern High-Rise Buildings. Buildings 2019, 9, 193. [CrossRef]

39. Moon, K.S. Comparative Evaluation of Structural Systems for Tilted Tall Buildings. Int. J. High-Rise Build. 2014, 2, 89-98.

40. Ali, M.M.; Moon, K.S. Structural Developments in Tall Buildings: Current Trends and Future Prospects. Archit. Sci. Rev. 2007, 50, 205-223. [CrossRef]

41. Taranath, B.S. Structural Analysis and Design of Tall Buildings: Steel and Composite Construction; CRC Press, Taylor \& Francis Group: Boca Raton, FL, USA, 2016.

42. Ali, M.M.; Moon, K.S. Advances in Structural Systems for Tall Buildings: Emerging Developments for Contemporary Urban Giants. Buildings 2018, 8, 104. [CrossRef]

43. Fu, F. Design and Analysis of Tall and Complex Structures; Butterworth-Heinemann, Elsevier: Oxford, UK; Cambridge, UK, 2018.

44. Trabucco, D. An analysis of the relationship between service cores and the embodied/running energy of tall buildings. Struct. Des. Tall Spec. Build. 2008, 17, 941-952. [CrossRef]

45. Yeang, K. The Skyscraper, Bioclimatically Considered; Academy Editions: London, UK, 1995.

46. Watts, S.; Kalita, N.; Maclean, M. The Economics of Super-Tall Towers. Struct. Des. Tall Spec. Build. 2007, 16, 457-470. [CrossRef]

47. Lundberg, H. Space Efficiency of Technical Installations in Tall Office Buildings. Master's Thesis, Department of Architecture and Civil Engineering, Division of Building Services Engineering, Chalmers University of Technology, Gothenburg, Sweden, 2019. 